\title{
USAHA KAYU RAKYAT DALAM SISTEM PENGHIDUPAN PETANI KECIL \\ (Kasus Desa Curug, Kecamatan Jasinga, Kabupaten Bogor)
}

\author{
Private Owned Timber Business In Peasant Household Livelihood Strategies \\ (Case study: In the village of Curug, Jasinga Subdistrict, Bogor District)
}

\author{
Ahmad Aulia Arsyad*), dan Satyawan Sunito \\ Departemen Sains Komunikasi dan Pengembangan Masyarakat, Fakultas Ekologi Manusia, IPB
}

*)Email : ahmadauliaarsyad@yahoo.com

\begin{abstract}
The purpose of this study was to analyze the role of the private owned timber business in peasant household livelihood strategies, in the village of Curug, Bogor District. An important factor that was known to have influence on private owned timber business was institution. So that needs to be analyzed how the role of institutions in supporting or inhibiting peasant household to access the private owned timber business. Qualitative approach through observation and depth interviews is used as the main approach when quantitative approach with a questionnaire instrument and review of literature related to the case is used to support qualitative data. Private owned timber business are not used as the main livelihood due to various reasons including long periode of harvest, can not be used as a daily income, and ownership of land is narrow so it can not be planted on a large scale. People tend to sell their wood still in the form of tree, and buyers do wholesale system, or buy all woody trees in public lands regardless the age of the trees.
\end{abstract}

Keywords: institution, livelihood strategies, private owned, timber bussiness

\begin{abstract}
ABSTRAK
Tujuan dari penelitian ini adalah untuk menganalisis peran usaha kayu rakyat dalam strategi nafkah rumah tangga petani, di Desa Curug, Kabupaten Bogor. Faktor penting yang diketahui dapat memengaruhi usaha kayu rakyat adalah kelembagaan. Oleh sebab itu perlu diketahui bagaimana peran kelembagaan dalam mendukung atau menghambat rumah tangga petani untuk mengakses usaha kayu kecil. Pendekatan kualitatif melalui observasi dan wawancara mendalam digunakan sebagai pendekatan utama, pada pendekatan kuantitatif dengan instrumen kuesioner dan tinjauan literatur yang sesuai dengan kasus digunakan untuk mendukung data kualitatif. Usaha kayu rakyat tidak digunakan sebagai mata pencaharian utama disebabkan oleh berbagai alasan termasuk masa panen yang panjang, tidak dapat digunakan sebagai pendapatan harian, dan kepemilikan lahan yang sempit sehingga tidak bisa ditanam dalam skala besar. Petani cenderung untuk menjual kayu mereka masih dalam bentuk pohon, dan pembeli membeli secara borongan, atau membeli semua pohon berkayu di lahan publik menghiraukan umur pohon.
\end{abstract}

Kata kunci : kelembagaan, sistem penghidupan, usaha kayu, usaha rakyat

\section{PENDAHULUAN}

Peluso (2006), menggambarkan bagaimana Indonesia yang kaya akan hutan beserta sumberdayanya ternyata justru membuat masyarakat, khususnya yang tinggal di sekitar hutan, menjadi semakin miskin. Hal ini diakibatkan adanya bentuk-bentuk penguasaan serta pengelolaan hutan sejak jaman kolonial Belanda yang menggeser posisi masyarakat sebagai subjek pemanfaat hutan tersebut. Sehingga masyarakat tidak dapat lagi memanfaatkan kawasan hutan di sekitar tempat tinggal mereka sendiri. Kepentingan politik dan ekonomi pemerintah terfokus pada eksploitasi sumberdaya dengan meminggirkan kepentingan masyarakat dan berdampak juga pada aspek kelestarian hutan tersebut. Seharusnya, sumberdaya yang merupakan milik rakyat, walaupun dititipkan pengelolaannya kepada negara, mampu menjadikan masyarakat menjadi sejahtera dan bukannya mengakibatkan pemelaratan rakyat seperti yang dijelaskan dalam buku tersebut.

Setelah kehilangan akses akan hutan yang biasa dimanfaatkan oleh masyarakat, timbul berbagai aksi yang dilakukan sebagai bentuk protes atas tindakan pemerintah. Penebangan liar semakin marak dan menyebabkan hutan terdegradasi secara bertahap. Hal demikian terjadi seiring bertambahnya jumlah penduduk yang mengakibatkan peningkatan kebutuhan hidup dan kebutuhan lahan masyarakat. Pemerintah juga berperan dalam pengkonversian hutan untuk kepentingan pembangunan, dengan kurang mempertimbangkan aspek kelestarian sumberdaya hutan tersebut.

Tekanan terhadap sumber daya hutan menyebabkan terjadinya eksploitasi yang berlebihan sehingga sumber daya hutan tidak mampu lagi memberikan manfaat yang optimal bahkan sebaliknya menyebabkan kerusakan dan 
menurunnya produktifitas sumber daya hutan. Di Pulau Jawa yang penduduknya paling padat di Indonesia, terlihat sekali tekanan terhadap sumber daya hutan untuk memenuhi kebutuhan hidup dan kebutuhan lahan. Tekanan untuk memenuhi kebutuhan lahan bagi pertanian, industri dan perumahan menyebabkan terjadinya konversi hutan menjadi lahan perumahan dan kawasan industri ataupun pertanian. Di lain pihak lahan kering yang tergolong sangat kritis atau kritis sangat luas. Salah satu usaha untuk merehabilitasi lahan kritis dan mengembangkan pemanfaatan lahan kering untuk menjadi lebih produktif adalah dengan menanam tanaman berkayu yang mempunyai nilai komersial di lahan milik penduduk, sekaligus menjawab permasalahan terutama masalah pembangunan sosial ekonomi penduduk di desa-desa (Departemen Kehutanan, 2008)

Berbagai penelitian tentang hutan rakyat telah dilakukan yang mencakup topik budidaya, pengaturan hasil, pemasaran, dan industri berbahan baku kayu dari hutan rakyat (Suharjito, 2002; Hardjanto, 2003; Hakim, et.al, 2009). Hutan rakyat dalam arti yang luas meliputi jaminan atas akses dan kontrol terhadap sumberdaya hutan untuk penghidupan masyarakat di dalam dan di sekitar kawasan hutan dimana mereka tergantung terhadapnya secara ekonomi, sosial, kultural, dan spiritual (Hinrich et.al, 2008). Hutan-hutan selayaknya dikelola untuk menjamin keamanan pemanfaatan dari generasi ke generasi berikutnya dan meningkatkan segala peluang kelestariannya.

Kayu dari hasil hutan rakyat, disebut juga kayu rakyat, memiliki potensi tinggi terhadap pendapatan petani. Hal ini dikarenakan pasokan kayu baik untuk ekspor maupun dalam negeri selagi hutan sebagai pemasok kayu, peranannya terus berkurang, sehingga pasaran terhadap kayu rakyat akan selalu ada. Pernyataan tersebut diperkuat oleh Hakim, (2009) yang menyebutkan bahwa kayu rakyat sudah menjadi alternatif sumber pemenuhan bahan baku bagi masyarakat dan industri perkayuan, sejalan dengan semakin berkurangnya pasokan kayu dari hutan produksi alam di luar Jawa dan Perhutani di Pulau Jawa.

Darusman (2001) juga mengatakan bahwa usaha kayu rakyat merupakan usaha yang kecil, namun tidak pernah mati, karena kebutuhan akan kayu akan selalu ada baik berupa bahan baku kayu, maupun barang jadi seperti perabotan rumahtangga. Masyarakat pemilik hutan rakyat cenderung menanam kayu pada lahan miliknya sebagai tabungan investasi jangka panjang yang sewaktu-waktu dapat diuangkan, karena keuntungan dari menjual kayu tidak dapat menjadi penghasilan sehari-hari bagi keluarga mereka. Petani cenderung menjual kayu berupa tegakan, atau masih berupa batang kayu, hanya sedikit sekali yang mulai melakukan pengolahan kayu tersebut dengan adanya industri kecil (Hardjanto, 2003).

Aspek kelembagaan hutan rakyat yang sudah ada, baik formal maupun informal, masih kurang diketahui. Perhatian dari pemerintah mengenai hal ini pun masih sangat minim. Sehubungan dengan itu, penelitian akan usaha kayu rakyat dalam sistem penghidupan petani ini menjadi sangat penting, karena segmen pasar kayu rakyat berbeda dengan segmen pasar kayu dari hutan alam produksi dari Luar Jawa dan dari Perum Perhutani baik dari segi mutu, harga, jenis industri penggunanya dan kontinuitas pasokan kayunya. Sehingga perlu diketahui dengan lebih jelas bagaimana kelembagaan usaha kayu rakyat berperan untuk mendukung sistem penghidupan petani.
Adanya potensi usaha kayu rakyat yang sangat besar, belum lagi dengan kebutuhan dan permintaan kayu yang semakin meningkat. Hal tersebut menjadikan usaha kayu rakyat sebuah kesempatan bagi masyarakat untuk mendapatkan penghasilan tambahan, bahkan dapat dijadikan mata pencaharian utama, sehingga usaha kayu rakyat ini menguntungkan masyarakat sebagai subjek pengelola hutan rakyat.

\section{Pertanyaan Penelitian}

Penelitian ini dilakukan dengan merangkum dua pertanyaan yakni: 1) apa peran usaha kayu rakyat di dalam strategi nafkah rumah tangga petani? 2) Bagaimana peran kelembagaan usaha kayu rakyat dalam mendukung atau menghambat keluarga petani untuk akses pada usaha kayu rakyat?

\section{Tujuan Penelitian}

Penelitian ini bertujuan: 1) menganalisis peran usaha kayu rakyat dalam strategi nafkah rumah tangga petani ; 2) menganalisis peran kelembagaan usaha kayu rakyat dalam mendukung atau menghambat keluarga petani untuk akses pada usaha kayu rakyat.

\section{Kegunaan Penelitian}

Penelitian ini berguna: 1) bagi akademisi, hasil penelitian ini diharapkan dapat menambah khazanah pengetahuan tentang strategi nafkah pekerja sektor informal khususnya para pedagang makanan di daerah suburban. Selain itu, penelitian ini diharapkan juga menambah khazanah literatur kajian mengenai strategi nafkah khususnya strategi nafkah pedagang makanan di sektor informal daerah suburban; 2) bagi pemerintah Kabupaten Bogor, hasil penelitian ini diharapkan menjadi sumber informasi yang bermanfaat untuk memberikan pertimbangan dalam pengambilan kebijakan terkait keberadaan sektor informal khususnya para pedagang makanan.

\section{METODE PENELITIAN}

\section{Lokasi dan Waktu Penelitian}

Penelitian ini dilakukan di Desa Curug, Kecamatan Jasinga, Kabupaten Bogor, Provinsi Jawa Barat selama bulan April - September 2011. Lokasi penelitian dipilih secara sengaja (purposive). Penentuan lokasi penelitian dilakukan dengan observasi dan melalui studi literatur. Hasil-hasil penelitian sebelumnya menunjukkan bahwa masyarakat Desa Curug, Kecamatan Jasinga, Kabupaten Bogor telah melakukan usaha kayu rakyat dengan kepemilikan lahan rata-rata di bawah $1 \mathrm{Ha}$. Hal ini menarik peneliti untuk mengkaji lebih dalam mengenai usaha kayu rakyat dalam sistem penghidupan petani kecil di daerah ini.

\section{Teknik Pengumpulan Data}

Penelitian ini bertujuan untuk menganalisis usaha kayu rakyat dalam sistem penghidupan petani kecil. Oleh karena itu, metode yang digunakan dalam melaksanakan penelitian ini adalah pendekatan kualitatif didukung dengan data-data kuantitatif. Data kualitatif dalam penelitian ini didapatkan dengan observasi dan wawancara mendalam kepada responden dan informan, dengan menggunakan alat bantu pedoman wawancara dan kuesioner. 
Pertanyaan dalam kuesioner terdiri dari pertanyaan tertutup dan pertanyaan terbuka. Pertanyaan tertutup digunakan untuk menghindari kesalahan persepsi antara jawaban yang diinginkan peneliti dengan jawaban yang diberikan responden, sedangkan pertanyaan terbuka digunakan untuk memberikan kebebasan terhadap responden untuk menjawab pertanyaan.

Unit analisa dalam penelitian ini adalah 30 rumahtangga petani yang melakukan usaha kayu rakyat di Desa Curug, Kecamatan Jasinga, Kabupaten Bogor dengan batasan setiap petani yang memiliki atau menggarap lahan dan menanam tanaman keras (kayu). Kemudian dilakukan wawancara mendalam dengan dua orang pedagang pengumpul dan satu orang pengusaha industri kayu lokal. Peneliti juga melakukan pendekatan terhadap seorang informan kunci mengenai gambaran umum usaha kayu rakyat yang dilakukan masyarakat Desa Curug. Selain itu peneliti melakukan observasi langsung ke lapangan untuk melihat usaha kayu rakyat yang dilakukan oleh masyarakat.

\section{Teknik Pengolahan dan Analisis Data}

Data yang diperoleh dalam penelitian ini baik secara kuantitatif maupun kualitatif diolah dengan cara mereduksi bagian-bagian terpenting sehingga menjawab masalah penelitian yang diajukan. Data yang diperoleh dari hasil rekapitulasi kuesioner responden diolah dan ditabulasi kemudian dianalisa secara deskriptif. Data kualitatif dari wawancara mendalam dan observasi disajikan secara deskriptif dan diperkuat oleh data kuantitatif. Gabungan dari data kuantitatif dan kualitatif diolah dan dianalisis dengan disajikan dalam bentuk teks naratif, matriks, bagan, dan gambar. Kemudian ditarik kesimpulan dari semua data yang telah diolah dan dipaparkan melalui penjelasan ilmiah.

\section{PERAN USAHA KAYU RAKYAT DALAM STRATEGI NAFKAH RUMAH TANGGA PETANI}

\section{Pengertian Strategi Nafkah Petani}

Petani di Desa Curug melakukan pilihan terhadap strategi nafkah yang berbeda-beda untuk menghidupi keluarganya. Berbagai usaha yang dilakukan meliputi usaha pertanian (sawah, kebun, usaha kayu rakyat), dan usaha di bidang non pertanian. Rata-rata masyarakat di Desa Curug memiliki sawah yang tidak terlalu luas, cukup untuk konsumsi sehari-hari saja, bahkan ada beberapa yang tidak memiliki sawah. Masyarakat Desa Curug cenderung memiliki lebih dari satu sumber nafkah.

Dapat dilihat pada Tabel 1, jumlah responden terbanyak memiliki tiga sumber nafkah dengan persentase lebih dari $50 \%$. Mata pencaharian utama masyarakat dominan menjadi buruh penyadap karet, baik di kebun sendiri, kebun keluarga, maupun kebun orang lain. Menyadap karet dilakukan dari pagi hingga tengah hari, dengan penghasilan sebesar Rp 12.000,00/liter. Setiap harinya seorang buruh sadap karet, baik laki-laki maupun perempuan, rata-rata dapat menghasilkan sekitar dua liter getah karet per hari. Hal itu dilengkapi oleh penanaman atau usaha budidaya kayu (sengon) pada lahan mereka sendiri.

Sebagian besar masyarakat Desa Curug memiliki sawah dengan frekuensi panen dua kali dalam satu tahun, dan cenderung subsisten. Berdasarkan data monografi Desa Curug, 70 persen mata pencaharian utama penduduk berada di bidang pertanian, dengan 30 persen keluarga beranggotakan buruh tani. Pertanian menjadi sumber nafkah utama bagi masyarakat Desa Curug, namun non pertanian juga merupakan sumber nafkah yang penting. Mubyarto dan Kartodirdjo (1988) menyebutkan bahwa peluang kerja bagi buruh tani dan petani gurem yang miskin nampaknya memang lebih banyak dapat diharapkan dalam kegiatan-kegiatan non-pertanian. Pada usaha non pertanian, sumber pendapatan masyarakat bervariasi dari menjadi staf desa, karyawan pabrik, guru, buruh, hingga tukang kredit. Masyarakat menjadikan usaha kayu rakyat sebagai sampingan, juga sebagai tabungan apabila pada saat-saat mendesak mereka memerlukan uang yang cukup banyak.

\section{Tabel 1. Jumlah dan Persentase Responden Berdasarkan Jumlah Sumber Nafkah}

\begin{tabular}{lrr}
\hline $\begin{array}{l}\text { Jumlah Sumber } \\
\text { Nafkah }\end{array}$ & Jumlah Responden & Persentase (\%) \\
\hline 1 & 0 & 0 \\
2 & 7 & 23,33 \\
3 & 17 & 56,67 \\
4 & 5 & 16,67 \\
5 & 1 & 3,33 \\
\hline Jumlah & 30 & 100 \\
\hline
\end{tabular}

Sumber : Data Primer, 2011

Menurut Mubyarto dan Kartodirdjo (1988) di negara kita, seperti juga negara-negara berkembang lain, karena harga-harga hasil pertanian pada umumnya selalu tertekan, sedangkan barang-barang non-pertanian harganya lebih leluasa naik, maka nilai tukar (term of trade) komoditi pertanian cenderung menurun. Akibatnya penghasilan mereka yang hidup dari kegiatan pertanian biasanya rendah dan tertekan. Bagi buruh tani dan petani gurem, yang banyak menggantungkan pendapatannya pada para pemilik tanah, peluang kerja dan berusaha menjadi sempit. Mereka kadang-kadang bekerja penuh, kadang-kadang tidak penuh. Tapi pada umumnya dapat dikatakan bahwa mereka bekerja keras (penuh) dengan penghasilan yang rendah sekali.

Keluarga-keluarga petani di Desa Curug cenderung menggantungkan sumber pendapatan kepala keluarga untuk memenuhi kebutuhan hidup. Walaupun memang terdapat wanita sebagai istri dari kepala keluarga, yang turut bekerja sebagai buruh tani atau pedagang untuk menambah penghasilan keluarga. Banyaknya jumlah anggota keluarga tidak mempengaruhi jumlah penghasilan keluarga mereka.

Anak yang beranjak dewasa cenderung mencari pekerjaan diluar desa untuk mencukupi kebutuhan hidup mereka, dan kemudian membentuk keluarganya sendiri. Meskipun demikian, menurut masyarakat ketersediaan tenaga kerja di Desa Curug tidak pernah berkurang.

Beberapa masyarakat yang ditemui peneliti mengemukakan bahwa mereka mempunyai keinginan untuk membuka usaha kerajinan dari bambu, baik berupa anyaman atau kerajinan lainnya. Hal ini dapat menambah nilai jual dari bambu yang banyak tumbuh di lahan mereka, dan membuka lapangan kerja bagi masyarakat. Namun keterampilan mengolah 
bambu tersebut kurang dikuasai oleh masyarakat, sehingga mereka terpaksa menjual batang-batang bambu yang belum diolah. Padahal jika mereka dapat mengolah bambu-bambu menjadi berbagai bentuk anyaman, nilai ekonomis dari bambu tersebut akan meningkat secara signifikan.

\section{Konstribusi Usaha Kayu Rakyat Terhadap Pendapatan Rumahtangga Petani}

Masyarakat mengakui mereka tertarik untuk memulai usaha kayu rakyat, dikarenakan melihat atau mendengar cerita-cerita keberhasilan tetangganya dalam melakukan usaha kayu rakyat. Apalagi pada saat tertentu mereka memerlukan uang dalam jumlah cukup banyak seperti untuk khitanan anak, pernikahan, dan lain-lain.

Salah seorang responden (HMA, 52 Tahun) menceritakan usahanya yang berawal dari petani biasa hingga menjadi salah seorang yang berpenghasilan lebih dari 5 juta per bulan.

"Waktu dulu saya cuman petani biasa aja, belajar dari bapak (almarhum). Lalu saya nyoba-nyoba jualan kayu punya bapak sama ngumpulin dari tetangga juga. Saya beli kayu-kayunya (tetangga), semacem manggis, kecapi, jengjeng, rambutan, kemudian saya jual lagi ke orang yang dateng nyari kayu. Waktu itu saya sempet menjabat jadi kepala desa juga. Karena untungnya lumayan (penghasilannya), saya beliin tanah buat tanam jengjeng (sengon). Sekarang saya udah pensiun tapi alhamdulillah pohonnya masih ada, kemarin habis jual juga (kayu)."

Pendapatan petani dari hasil penjualan pohon berdiri sangat bervariasi tergantung kebutuhan masing-masing petani. Jika kebutuhan uang banyak dan mendesak maka petani akan menjual semua kayunya kepada pembeli dengan harga yang dirasa cocok tanpa pikir panjang dan tanpa memperhitungkan usia dari pohon-pohon yang ditebang (tebang habis). Sebaliknya apabila kebutuhan uang tidak terlalu mendesak maka petani lebih mempertimbangkan keuntungan sebesar-besarnya, yaitu pembeli dengan harga paling tinggi dengan memperhitungkan usia pohon mereka.

Beberapa orang masyarakat yang ditemui pada saat penelitian mengaku bahwa kayu-kayu yang digunakan untuk membangun rumah mereka berasal dari kayu-kayu di lahan mereka sendiri ataupun membeli dari tetangga mereka. Seperti dituturkan oleh JAR (70 tahun) yang mengaku menjual pohon kecapi dan manggisnya.

"Setelah bapak meninggal dua tahun lalu, yang saya punya y a cuma rumah ini sama pohon-pohon yang tadinya diurus bapak. Anak-anak pada keluar (kerja dan berkeluarga sendiri), ya untuk nambah uang saya jual saja (pohon) ambon (sengon), kecapi, sama manggis bapak, daripada ga keurus. Sisanya (kayu) buat benerin rumah sama masak (kayu bakar)."

Masyarakat Desa Curug rata-rata menjual pohon sengon milik mereka pada usia 5 tahun. Pada saat penelitian, beberapa informan menyebutkan harga jual satu pohon sengon dengan diameter 20-30 cm adalah Rp 400.000,00.

Tabel 2 menunjukan keuntungan responden per tahun dari hasil penjualan kayu rakyat, yang diperoleh melalui perhitungan antara penghasilan usaha kayu rakyat per siklus panen dibagi usia panen pohon.
Tabel 2. Kontribusi Usaha Kayu Rakyat terhadap Total Pendapatan Rumahtangga Petani Per Tahun 2011

\begin{tabular}{|c|c|c|c|c|c|}
\hline \multirow[t]{2}{*}{ No. } & \multirow[t]{2}{*}{$\begin{array}{l}\text { Usia } \\
\text { panen } \\
\text { kayu } \\
\text { (thn) }\end{array}$} & \multicolumn{2}{|c|}{$\begin{array}{l}\text { Pendapatan } \\
\begin{array}{c}\text { usaha kayu } \\
\text { rakyat }\end{array} \\
\text { ( X Rp 1000) }\end{array}$} & \multirow{2}{*}{$\begin{array}{c}\text { Total } \\
\text { pendapa- } \\
\text { tan perta- } \\
\text { hun } \\
\text { (X Rp } \\
1000)\end{array}$} & \multirow[t]{2}{*}{$\begin{array}{c}\text { Kontribusi } \\
\text { usaha kayu } \\
\text { rakyat } \\
(\%)\end{array}$} \\
\hline & & $\begin{array}{c}\text { Per } \\
\text { panen }\end{array}$ & $\begin{array}{l}\text { Per } \\
\text { thn }\end{array}$ & & \\
\hline 5 & 4 & 30.000 & 7.500 & 60.000 & 12.5 \\
\hline 6 & 3 & 16.000 & 5.333 & 60.000 & 8.8 \\
\hline 1 & 5 & 4.000 & 800 & 60.000 & 1.3 \\
\hline 7 & 3 & 10.000 & 3.333 & 36.000 & 9.2 \\
\hline 11 & 5 & 7.000 & 1.400 & 36.000 & 3.8 \\
\hline 10 & 6 & 6.000 & 1.000 & 36.000 & 2.7 \\
\hline 2 & 5 & 4.000 & 800 & 36.000 & 2.2 \\
\hline 26 & 5 & 4.000 & 800 & 36.000 & 2.2 \\
\hline 25 & 5 & 3.000 & 600 & 36.000 & 1.6 \\
\hline 4 & 4 & 4.000 & 1.000 & 24.000 & 4.1 \\
\hline 23 & 4 & 3.000 & 750 & 24.000 & 3.1 \\
\hline 3 & 5 & 2.500 & 500 & 24.000 & 2.0 \\
\hline 27 & 4 & 1.000 & 250 & 24.000 & 1.0 \\
\hline 12 & 7 & 800 & 114 & 24.000 & 0.4 \\
\hline 24 & 3 & 400 & 133 & 18.000 & 0.7 \\
\hline 30 & 5 & 500 & 100 & 14.400 & 0.6 \\
\hline 8 & 5 & 5.000 & 1.000 & 12.000 & 8.3 \\
\hline 18 & 5 & 3.000 & 600 & 12.000 & 5.0 \\
\hline 20 & 5 & 500 & 100 & 12.000 & 0.8 \\
\hline 22 & 5 & 500 & 100 & 6.000 & 1.6 \\
\hline 16 & 6 & 500 & 83 & 6.000 & 1.3 \\
\hline 29 & $\begin{array}{l}\text { belum } \\
\text { jual }\end{array}$ & - & - & 60.000 & - \\
\hline 21 & $\begin{array}{l}\text { belum } \\
\text { jual }\end{array}$ & - & - & 36.000 & - \\
\hline 13 & $\begin{array}{c}\text { belum } \\
\text { jual }\end{array}$ & - & - & 24.000 & - \\
\hline 28 & $\begin{array}{l}\text { belum } \\
\text { jual }\end{array}$ & - & - & 24.000 & - \\
\hline 9 & $\begin{array}{l}\text { belum } \\
\text { jual }\end{array}$ & - & - & 12.000 & - \\
\hline 14 & $\begin{array}{l}\text { belum } \\
\text { jual }\end{array}$ & - & - & 12.000 & - \\
\hline 17 & $\begin{array}{l}\text { belum } \\
\text { jual }\end{array}$ & - & - & 12.000 & - \\
\hline 19 & $\begin{array}{l}\text { belum } \\
\text { jual }\end{array}$ & - & - & 12.000 & - \\
\hline 15 & $\begin{array}{l}\text { belum } \\
\text { jual }\end{array}$ & - & - & 6.000 & - \\
\hline
\end{tabular}

Sumber : Data Primer, 2011 
Total pendapatan pertahun didapat berdasarkan keterangan penghasilan keluarga responden perbulan, dikalikan 12 bulan. Tingkat kontribusi usaha kayu rakyat yang masih rendah disebabkan produktivitas usaha kayu rakyat dan harga jual kayu yang rendah. Harga jual kayu yang diterima petani lebih rendah dari harga pasar, karena petani menjual kayu dengan sistem ijon atau tebang butuh.

Sehingga persentasi kontribusi usaha kayu rakyat responden pertahun dihitung melalui keuntungan usaha kayu rakyat pertahun dibagi total pendapatan rumahtangga pertahun.

$$
\begin{aligned}
& \text { Pendapa- Pendapatan usaha } \\
& \text { tan usaha } \\
& \text { kayu rakyat } \\
& \text { pertahun } \\
& =\frac{\text { kayu rakyat per panen }}{\text { Usia panen }} \\
& \begin{array}{c}
\text { Kontribusi } \\
\begin{array}{c}
\text { usaha kayu } \\
\text { rakyat }
\end{array}
\end{array}=\frac{\begin{array}{c}
\text { Pendapatan usaha kayu } \\
\text { rakyat pertahun }
\end{array}}{\begin{array}{c}
\text { Total pendapatan rumahtang- } \\
\text { ga pertahun }
\end{array}} \quad \begin{array}{c}
10 \% \\
\text { nan }
\end{array}
\end{aligned}
$$

Peran pendapatan dari usaha kayu rakyat menjadi sangat penting pada saat pelaku usaha kayu rakyat membutuhkan dana yang cukup besar untuk membiayai hal tertentu seperti berobat, nikahan anak, khitanan anak, pendidikan, dan sebagainya. Hal ini dikarenakan pendapatan masyarakat perbulan biasanya telah dialokasikan untuk berbagai keperluan rumahtangga, sehingga pada saat tertentu keluarga membutuhkan dana lebih yang bisa dikeluarkan seperti layaknya tabungan. Kayu dalam hal ini berperan sebagai tabungan jangka panjang, dan dapat ditebang pada usia yang telah diperhitungkan, ataupun pada saat dibutuhkan.

Berdasarkan data penelitian, kontribusi penghasilan dari hasil usaha kayu rakyat cenderung dibawah 5\% dari total pendapatan keluarga pertahun. Hal ini dikarenakan penjualan kayu rakyat oleh unit usaha kayu rakyat pada tingkat keluarga belum terpola dengan baik. Kepemilikan lahan yang terbatas, menjadi salah satu pengaruh yang berarti bagi produktivitas kayu rakyat. Bagi masyarakat dengan lahan luas, siklus panen kayu rakyat dapat terjadi setiap tahun, dua tahun sekali, atau tiga tahun sekali. Sedangkan bagi masyarakat yang hanya menanam kayu pada lahan-lahan sisa seperti pekarangan, siklus panen kayu hanya dapat terjadi setiap tiga sampai lima tahun sekali sesuai umur panen kayu sengon yang ditanam. Namun dengan melihat Tabel 2 dan Tabel 3, secara umum dapat disimpulkan bahwa responden yang total pendapatannya lebih besar cenderung memiliki pendapatan dari usaha kayu rakyat yang lebih besar. Hal ini dikarenakan petani tersebut memiliki lahan yang lebih luas, maupun pendapatan berlebih yang dapat digunakan untuk menanam kayu lebih banyak.

Jumlah pohon yang dipanen tiap siklus kayu rakyat menjadi pengaruh selanjutnya dari besaran kontribusi kayu rakyat terhadap total pendapatan masyarakat. Bagi masyarakat dengan lahan relatif sempit, mereka hanya dapat menanam beberapa batang pohon, bahkan pada saat penelitian ditemukan masyarakat yang hanya memiliki dua hingga tiga batang pohon sengon yang ditanam di pekarangan rumah.

Masyarakat dengan lahan yang lebih luas dapat menanam lebih banyak pohon sengon, baik berdampingan dengan karet, maupun monokultur. Hal tersebut menjadi sebuah peluang bagi pelaku usaha kayu rakyat untuk melakukan rotasi tanam dan panen kayu, sehingga penghasilan dari usaha kayu rakyat menjadi semakin besar bila dihitung pertahun, dan meningkatkan nilai kontribusi usaha kayu rakyat terhadap total pendapatan rumahtangga petani.

Tabel 3. Jumlah Responden menurut Persentase Kontribusi Usaha Kayu Rakyat Terhadap Total Pendapatan Rumahtangga Petani

\begin{tabular}{lrr}
\hline $\begin{array}{l}\text { Kontribusi Usaha Kayu } \\
\text { Rakyat (\%) }\end{array}$ & Jumlah Responden & $(\%)$ \\
\hline Belum ada & 9 & 30 \\
$<5$ & 17 & 57 \\
$5,1-10$ & 3 & 10 \\
$>10$ & 1 & 3 \\
Jumlah & 30 & 100 \\
\hline Sumber : Data Primer, 2011
\end{tabular}

\section{KELEMBAGAAN USAHA KAYU RAKYAT}

\section{Kelembagaan Pengurusan Hutan Rakyat}

Usaha kayu rakyat tidak menjadi mata pencaharian utama karena berbagai alasan antara lain usia panen yang lama, tidak dapat dijadikan penghasilan sehari-hari, dan kepemilikan lahan yang sempit, sehingga tidak dapat melakukan penanaman dalam skala besar. Walaupun demikian, beberapa masyarakat mengakui justru dengan lahan mereka yang terbatas, mereka lebih memilih untuk menanam kayu daripada tanaman budidaya lainnya sebagai tabungan apabila sewaktu-waktu dibutuhkan (tebang butuh). Menanam kayu juga diakui tidak sulit, masyarakat memperoleh bibit dari hutan, dan setelah penanaman tidak terlalu membutuhkan perawatan yang intensif.

Masyarakat Desa Curug sebagian besar tidak mengakui adanya norma ataupun aturan-aturan khusus yang berlaku mengenai usaha kayu rakyat. Baik berupa adat setempat ataupun aturan yang memang diberlakukan oleh pemerintah. Akan tetapi pemerintah desa setempat mengakui bahwa sebenarnya terdapat sebuah aturan khusus mengenai usaha kayu rakyat ini. Seharusnya terdapat pencatatan dalam setiap batang kayu yang keluar dari tanah desa, atau disebut juga SKAU (Surat Keterangan Asal Usul) kayu, sehingga desa dapat memonitor setiap kayu yang keluar. Namun pada kenyataannya aturan ini tidak diakui wajib oleh masyarakat setempat, dan kebanyakan tidak melaksanakannya. Seperti dituturkan oleh AER (30), seorang staf desa berikut.

"Sebenarnya ada aturan kepada masyarakat untuk melaporkan setiap menjual kayu, ya memang ada biaya semacam retribusi sebesar 10\% dari hasilnya. Itu digunakan untuk keperluan administrasi saja, dan fleksibel juga, tidak harus segitu, seikhlasnya saja. Namun masyarakat tidak ada yang peduli, tidak melaporkan. Kan kita yang bingung, mau laporan ke kecamatan juga gimana."

Masalah lain yang ditemukan di lokasi penelitian adalah masyarakat dipersulit dengan aturan seperti SKSHH (Surat Keterangan Sahnya Hasil Hutan) dan SIT (Surat Izin Tebang), khususnya untuk membudidayakan tanaman Jati (Tectona grandis) dan Mahoni (Swietenia macrophylla). Masyarakat menjadi segan untuk membudidayakan 
tanaman Jati dan Mahoni karena kesulitan mengurus SKSHH dan SIT. Petani kayu mengakui mereka lebih memilih untuk membudidayakan tanaman sengon (Paraserianthes falcataria) karena tidak memerlukan ijin khusus untuk menanam atau menebang tanaman tersebut.

Pengertian dan penafsiran serta program pengembangan tentang Hutan Rakyat sudah harus disesuaikan dengan kondisi di lapangan supaya pengembangan teknologi, manajemen, dan kelembagaan Hutan Rakyat lebih intensif dan inovatif untuk memelihara budaya masyarakat dalam membudidayakan tanaman kehutanan di lahan miliknya. Pengertian-pengertian tersebut, jangan sampai menimbulkan kesan sebagai bentuk intervensi pemerintah yang kontra produktif bagi pengembangan gerakan penanaman pohon yang sedang digalakkan. Pengelolaan tanaman kayu oleh rakyat yang dikembangkan secara swadaya, dengan modal biaya, lahan dan tenaga kerja sendiri harus terlepas dari berbagai hambatan birokratis. Aturan SKSHH dan SIT harus dibuat untuk dalam rangka penataan, pengaturan, dan pengurusan serta pengembangan Hutan Rakyat yang berorientasi kelestarian lingkungan dan peningkatan kesejahteraan masyarakat dalam arti luas.

Pada saat penelitian, tidak ditemukan adanya usaha pembibitan yang dilakukan oleh masyarakat Desa Curug. Hampir seluruh responden mengakui bahwa mereka mendapatkan bibit dari hutan, sehingga tidak ada biaya yang dikeluarkan untuk membeli bibit. Kegiatan budidaya sengon diakui sudah menjadi tradisi lama di Desa Curug. Beberapa responden mengatakan bahwa sejak habisnya masa HGU PTP. Jasinga, masyarakat mulai menanam pohon sengon untuk mengisi tanah-tanah kosong milik mereka. Hal ini dilakukan setelah adanya tanda terima dan persetujuan pemerintah atas permohonan penggarapan tanah adat oleh masyarakat. Sejak saat itu, kegiatan budidaya sengon menjadi usaha sampingan yang banyak dilakukan masyarakat.

Masyarakat Desa Curug yang menanam pohon sengon pada lahan-lahan milik mereka, biasanya dicampur dengan tanaman lain seperti karet, kecapi, dan tanaman buah-buahan pada lahan yang berkisar antara 0,5-1 Ha. Petani pemilik lahan yang lebih luas dari $1 \mathrm{Ha}$ cenderung menanam sengon dan karet pada lahan yang berbeda (monokultur) dengan jarak tanam $3 \times 3$ meter ${ }^{2}$, sedangkan petani berlahan sempit atau dalam hal ini kurang dari 0,5 Ha menanam sengon dimana saja terdapat lahan miliknya yang kosong seperti sekeliling rumah atau di pinggir sawah mereka.

Tanaman Sengon dipilih sebagai usaha kayu rakyat dikarenakan usia panennya yang relatif lebih pendek jika di bandingkan tanaman kayu lain, yaitu 4-5 tahun sudah memiliki diameter sekitar 20-30 cm dengan harga mencapai 400 ribu rupiah per pohon. Selain itu, setelah batang sengon ditebang akan muncul sedikitnya dua tunas baru yang akan tumbuh kembali. Sehingga keuntungan selanjutnya akan menjadi lebih besar. Siklus hidup satu pohon sengon tersebut akan berulang setidaknya 3 kali. Setelah 3 kali dilakukan penebangan, pohon tersebut sudah menurun kualitas kayunya sehingga harus dilakukan penebangan habis dan menanam bibit yang baru.

Pemanenan kayu rakyat dilakukan berdasarkan sistem tebang butuh yang menyebabkan konsep kelestarian hasilnya belum berdasarkan kepada kontinuitas hasil yang dapat diperoleh dari perhitungan pemanenan yang sebanding dengan pertumbuhan (riap) tanaman. Konsep kontinuitas hasil tidak terlalu dipertimbangkan oleh masyarakat, selain karena desakan kebutuhan ekonomi dan kepemilikan lahan yang relatif sempit, dengan jumlah pohon yang tidak terlalu banyak, pembeli/pengumpul di daerah ini terbiasa melakukan sistem borongan atau membeli semua pohon kayu yang masih berdiri tegak, tanpa mempertimbangkan usia dari pohon-pohon tersebut. Hal tersebut mungkin menjadi sebuah konsep kontinuitas yang dilakukan oleh pengumpul, karena mereka melakukan daur pemanenan secara bergiliran dari tiap lahan masyarakat.

\section{Kelembagaan Sosial}

Aktor-aktor usaha kayu rakyat meliputi petani kayu, pedagang pengumpul, "gesekan" atau penggergaji kayu, kemudian industri kayu. Selanjutnya hasil olahan industri dipasarkan kembali sebagai barang jadi/setengah jadi. Pada lokasi penelitian, tidak terlalu tampak adanya hubungan sosial yang kuat antar aktor usaha kayu rakyat. Jenis dan jumlah pohon yang ditanam, serta penjualan batang-batang pohon kayu rakyat ditentukan oleh keluarga petani, sedangkan harga kayu rakyat masih ditentukan oleh pembeli dan pengguna. Petani kayu tidak selalu menjual pohon-pohon mereka kepada orang yang sama, melainkan kepada orang yang terlebih dahulu menawarkan harga tertinggi. Penjualan pohon-pohon kayu rakyat lebih dipengaruhi oleh kebutuhan petani kayu rakyat. Walaupun petani hanya mendapatkan bagian harga yang relatif rendah dibandingkan dengan pedagang dan pengguna (industri) kayu rakyat, masyarakat Desa Curug tetap banyak menanam pohon kayu.

Berdasarkan hasil penelitian, dapat diambil kesimpulan bahwa norma yang dijadikan pedoman bertindak individu tergolong pada tindakan rasional-komersial. Masyarakat mengetahui adanya aturan tersebut, tetapi tidak melaksanakannya dengan alasan bahwa setiap batang kayu yang keluar dari lahan mereka adalah milik mereka dengan usaha mereka sendiri. Sehingga tidak ada campur tangan dari pemerintah desa. Selain itu masyarakat tidak mau melaporkan kepada pemerintah desa karena mereka harus membayar pungutan administrasi dari pemerintah desa, yang menurut pemerintah desa sebenarnya hanya sekedar biaya seikhlasnya saja. ELI (38 Tahun) mengakui bahwa memang masyarakat sebenarnya tahu adanya peraturan tersebut, namun menolak untuk melakukannya dikarenakan merasa peraturan tersebut menyulitkan.

"Memang ada peraturan dari desa buat melapor setiap jual kayu, tapi ada biayanya. Masa kita yang tanam sendiri, jual sendiri, harus lapor, bayar lagi. Desa kan ga ada urusan harusnya."

Pemerintah di satu pihak harus melakukan pengendalian terhadap produksi dan distribusi serta harga dan mutu kayu (termasuk kayu rakyat) dalam menggairahkan dunia usaha perkayuan dan peningkatan kesejahteraan masyarakat, di lain pihak di bagian hulu aspek konservasi dan rehabilitasi melalui program pemerintah dengan gerakan penanaman pohon harus berhasil dengan baik. Hutan Rakyat yang telah menjadi salah satu sumber bahan baku industri kayu rakyat merupakan salah satu indikator keberhasilan gerakan penanaman oleh pemerintah.

Pada lokasi penelitian tidak ditemukan kelembagaan formal untuk mewadahi usaha kayu rakyat yang dilakukan masyarakat, baik berupa kelompok tani maupun koperasi. 
Basis pengelolaan usaha kayu rakyat berada pada tingkat keluarga, dimana setiap keluarga melakukan pengembangan dan pengaturan secara terpisah satu sama lain.

\section{Kelembagaan Ekonomi}

Masyarakat mengakui untuk pemasaran kayu sengon cukup mudah dilakukan. Bahkan mereka tidak perlu melakukan strategi pemasaran khusus untuk menjual kayu-kayu mereka. Hal ini dikarenakan pembeli/pengumpul akan datang sendiri ke lahan-lahan masyarakat untuk membeli/ menawar pohon mereka. Petani kayu menjual kayu-kayu mereka dalam bentuk tegakan pohon berdiri, dan biaya serta proses penebangan hingga pengangkutan ditanggung oleh pembeli/pengumpul tersebut.

Penelitian Hakim (2009) menunjukkan bahwa produksi kayu rakyat jenis Sengon di wilayah Jawa Bagian Barat tertinggi adalah di Kabupaten Bogor, disusul Kabupaten Lebak dan kemudian Kabupaten Ciamis. Sedangkan untuk produksi kayu rakyat jenis Jati dan Mahoni, Kabupaten Bogor sangat tertinggal jauh dari Kabupaten Ciamis. Meskipun demikian, saat ini mulai diberlakukan Sistem Verifikasi Legalitas Kayu (SVLK) yang diatur dengan Permenhut No. P.38/MenhutII/2009 dan Perdirjen terkait yang mencakup kawasan hutan produksi, hutan rakyat (hutan hak), serta industri perkayuan. Sehingga tantangan bagi pengembangan usaha kehutanan masyarakat semakin besar.

SVLK diberlakukan untuk menjawab persoalan legalitas kayu, baik dari hutan negara maupun hutan rakyat. Kebijakan ini juga diberlakukan terhadap setiap industri perkayuan, sehingga untuk mempertahankan status kayu legal, perlu dipastikan dari hulu hingga hilir. Bahkan kini kayu sengon pun mulai dikenakan peraturan SVLK, yang berarti memerlukan tambahan biaya bagi petani kayu. Peraturan tersebut secara langsung akan mengurangi pendapatan petani dari usaha kayu rakyat. Masyarakat disarankan untuk mengelompok dan mengurus legalitas kayu mereka, karena status legalitas kayu berpengaruh terhadap harga jual kayu atau barang berbahan baku kayu tersebut.

Berdasarkan keterangan di lapangan, kayu-kayu yang sudah ditebang tersebut kemudian dibawa oleh pengumpul ke tempat penggergajian kayu, sering disebut juga "gesekan" atau "bengkel kayu", dimana kemudian kayukayu tersebut diolah untuk dibentuk menjadi berbagai macam keperluan seperti papan, peti kemas, dan lain-lain. Industri kayu seperti ini sayangnya belum terdapat di Desa Curug, sehingga kayu-kayu tersebut dibawa ke tempat lain, bahkan sampai keluar kota seperti Banten, Sukabumi, Bekasi, hingga Jawa Tengah.

Pengumpul yang membeli kayu-kayu dari lahan masyarakat kebanyakan berasal dari luar desa. Mereka secara berkala mengunjungi lahan-lahan masyarakat untuk memborong kayu. Dalam satu siklus panen kayu di beberapa lahan masyarakat, pengumpul yang memborong kayu-kayu tersebut bisa berbeda orang dengan pengumpul di siklus berikutnya. Dapat dikatakan bahwa masyarakat tidak menjual kayu mereka ke orang tertentu atau langganan. Pengumpul yang berasal dari dalam desa hanya ditemukan 2 orang pada saat penelitian, mereka melakukan usaha budidaya sengon serta membeli kayu-kayu dari tetangga, untuk kemudian dijual ke tempat penggergajian kayu di luar desa.
Harga kayu rakyat masih ditentukan oleh pembeli dan pengguna. Hal ini sejalan dengan pernyataan Hakim (2009), bahwa harga kayu rakyat di pasaran ditentukan oleh tingkat penawaran dan permintaan di pasaran. Tingkat penawaran akan kayu rakyat dapat dilihat dari tingkat pertumbuhan industri berbahan baku kayu rakyat. Tekanan terhadap potensi kayu dari hutan rakyat sangat tinggi, akan tetapi petani hanya mendapatkan bagian harga yang relatif rendah dibandingkan dengan pedagang dan pengguna (industri) kayu rakyat. Bahkan keterbatasan pasokan kayu dari luar Jawa menyebabkan ancaman terhadap kelestarian Hutan Rakyat. Dorongan kebutuhan hidup petani yang sulit menyebabkan kayu berumur pendek dan jenis-jenis kayu buah-buahan seperti durian, manggis, mangga, nangka dan kecapi menjadi sasaran untuk ditebang.

Faktor-faktor yang menyebabkan rendahnya posisi tawar petani adalah lemahnya permodalan dan rendahnya akses terhadap pasar dan industri pengguna bahan baku kayu rakyat. Akan tetapi secara lokal, para petani sudah banyak berhasil dalam mengembangkan Hutan Rakyat. Kayu Rakyat sudah banyak meramaikan pasaran kayu dan mengisi pasokan industri kayu di sentra-sentra industri kayu dan perumahan rakyat.

Mekanisme perdagangan kayu rakyat berada diluar kendali petani kayu rakyat sebagai produsen, sehingga keuntungan terbesar dari pengelolaan hutan rakyat tidak dirasakan oleh petani kayu rakyat. Menurut Hardjanto (2003), peran Kelompok Tani Hutan dan Asosiasi Kelompok Tani Hutan Rakyat harus diberdayakan untuk meningkatkan posisi tawar petani. Untuk menjaga kesinambungan usaha hutan rakyat sengon, maka diperlukan upaya perlindungan kepada petani dari pihak pemerintah dan upaya penguatan kelembagaan petani misalnya membentuk kelembagaan usaha bersama (mitra) antara petani dengan pihak pengusaha industri pengolahan kayu sengon.

Masyarakat Desa Curug belum melakukan pengolahan kayu dalam bentuk industri berbahan baku kayu rakyat. Jumlah responden yang ditemui pada saat penelitian hampir seluruhnya melakukan usaha budidaya kayu rakyat seperti terlihat pada Tabel 4.

Tabel 4. Jumlah dan Persentase Responden menurut Aktifitas Usaha Kayu Rakyat yang Dilakukan

Usaha Kayu Rakyat Persentase (\%)

Usaha budidaya

Buruh tani dalam usaha budidaya

Sewa/bagi hasil dalam usaha budidaya

Usaha perdagangan kayu

rakyat

Sumber : Data Primer, 2011

Kurangnya modal diakui masyarakat sebagai penghambat usaha kayu rakyat mereka. Hampir seluruh responden mengakui kalau mereka mendapatkan bantuan berupa modal, baik dalam bentuk bibit, lahan, maupun dana tunai, mereka memiliki keinginan untuk mengembangkan usaha 
mereka. Peneliti menemukan beberapa warga desa (bukan responden) yang berniat untuk memulai industri pengolahan kayu menjadi peti-peti telur kecil-kecilan, namun terhambat dengan masalah modal. Usaha pembuatan peti-peti telur tersebut baru berjalan dua minggu pada saat penelitian, dan mereka mengakui mendapatkan bahan dengan membeli kayu-kayu yang sudah digergaji menjadi bentuk papan dari "gesekan" di luar desa.

\section{KESIMPULAN}

Berdasarkan tujuan dan masalah penelitian yang telah disusun di pendahuluan, maka terdapat tiga kesimpulan untuk menjawah masalah penelitian tersebut yaitu: (1) petani di Desa Curug melakukan pilihan terhadap strategi nafkah yang berbeda-beda untuk menghidupi keluarganya. Berbagai usaha yang dilakukan meliputi usaha pertanian (sawah, kebun, usaha kayu rakyat), dan usaha di bidang non pertanian. Sebagian besar $(76,67 \%)$ rumahtangga memiliki sumber nafkah lebih dari dua, dan usaha kayu rakyat merupakan salah satu sumber nafkah yang memiliki posisi strategis walaupun dalam persentasi kontribusinya terhadap total pendapatan pertahun tidak besar. (2) usaha pertanian karet dan sawah cenderung menjadi sumber nafkah utama keluarga petani, dengan usaha kayu rakyat dan non-pertanian sebagai sumber nafkah sampingan. Hal ini dibedakan oleh pelaku usaha (kepala keluarga, istri, anak), porsi waktu kerja, dan besarnya pendapatan dari sumber nafkah tersebut. (3) posisi usaha kayu rakyat dalam strategi nafkah petani adalah sebagai sumber nafkah sampingan yang strategis dengan sistem "tebang butuh", yaitu penjualan pohon kayu pada saat petani membutuhkan uang dalam jumlah besar segera. Hal ini dipengaruhi oleh kebutuhan petani. Saat kebutuhan akan uang mendesak, petani akan menjual sebagian besar atau seluruh kayunya. Pada saat kebutuhan petani tidak terlalu terdesak, petani hanya menjual sedikit kayunya, dengan harga tawaran tertinggi, atau tidak menjual sama sekali. (4) semakin luas lahan yang dimiliki, petani kayu rakyat cenderung menanam lebih banyak pohon kayu. (5) hubungan antar aktor dalam usaha kayu rakyat tidak terlalu berperan terhadap akses keluarga petani pada usaha kayu rakyat di Desa Curug, karena basis pengambilan keputusan serta sistem pengelolaan kayu rakyat berada pada level keluarga. (6) faktor-faktor yang menyebabkan rendahnya posisi tawar petani antara lain lemahnya permodalan, dan rendahnya akses terhadap pasar dan industri pengguna bahan baku kayu rakyat, sehingga masyarakat tidak memiliki kekuatan untuk meningkatkan posisi tawar mereka di pasaran kayu. (7) Kelembagaan berupa aturan maupun kebijakan pemerintah yang ada cenderung melemahkan akses petani terhadap usaha kayu rakyat.

\section{DAFTAR PUSTAKA}

Attar, Muhammad. 1998. Hutan Rakyat: Kontribusi Terha dap Pendapatan Rumah Tangga Petani dan Perannya dalam Perekonomian Desa (Studi Kasus di Desa Sumberejo, Kabupaten Wonogiri, Jawa Tengah), dalam Suharjito, Didik (ed.), 2000. Hutan Rakyat di Jawa. Program Penelitian dan Pengembangan Kehutanan Masyarakat (P3KM), Fakultas Kehutanan Institut Pertanian Bogor.

Badan Pusat Statistik. 2008. Potensi Desa (ID). Jakarta: BPS
Darusman, Dudung. 2001. Pendahuluan, dalam Darusman, Dudung (ed.), 2001. Resiliensi Kehutanan Masyarakat di Indonesia. Yogyakarta: Debut Press.

Dharmawan, AH. 2007. Sistem Penghidupan dan Nafkah Pedesaan Pandangan Sosiologi Nafkah (Livelihood Sociology) Mazhab Barat dan Mazhab Bogor. Sodality: Jurnal Transdisiplin Sosiologi, Komunikasi, dan Ekologi Manusia. Vol. 01 No.02, Agustus. Hal. 169-192.

Etzioni, Amitai. 1982. Organisasi-organisasi Modern. Jakarta: UI Press

Hakim. 2009. Kajian Peredaran Kayu Rakyat di Wilayah Jawa Bagian Barat. Jurnal Penelitian Sosial dan Ekonomi Kehutanan Vol. 6 No. 1, Maret, Hal. 1537.

Hardjanto. 2006. Model Struktural Sistem Usaha Kayu Rakyat. Jurnal Manajemen Hutan Tropika, Volume XII Nomor 2, hal. 57-68.

Hardjanto. 2003. Keragaan dan Pengembangan Usaha Kayu Rakyat di Pulau Jawa. Disertasi. Bogor: Institut Pertanian Bogor.

Hardjanto. 2001. Dampak Krisis Ekonomi dan Moneter terhadap Usaha Kehutanan Masyarakat di Jawa. Fakultas Kehutanan. Institut Pertanian Bogor.

Hinrichs, Alexander,. Dwi R. Muhtaman, dan Nawa Irianto. 2008. Sertifikasi Hutan Rakyat di Indonesia. Deutsche Gesellschaft für Technische Zusammenarbeit (GTZ).

Jariyah, Nur Ainun dan Nining Wahyuningrum. 2008. Karakteristik Hutan Rakyat di Jawa. Jurnal Penelitian Sosial dan Ekonomi Kehutanan Volume 5 Nomor 1, Maret, hal. 43-56.

Maryudi, Ahmad. 2005. Beberapa Kendala Bagi Sertifikasi Hutan Rakyat. Jurnal Hutan Rakyat, Volume VII No. 3, hal. 25-36.

Mubyarto. 1988. Sistem dan Moral Ekonomi Indonesia. Jakarta: LP3ES.

Peluso, Nancy Lee. 2006. Hutan Kaya, Rakyat Melarat. Jakarta: KONPHALINDO.

Singarimbun, Masri dan Efendi, Sofian (ed.). 2008. Metode Penelitian Survei (cetakan kesembilanbelas). Jakarta: LP3ES.

Soekanto, Soerjono. 1981. Sosiologi Suatu Pengantar. Jakarta: UI Press.

Soemardjan, Selo dan Soelaeman Soemardi. 1964. Setangkai Bunga Sosiologi. Jakarta: Lembaga Penerbit Fakultas Ekonomi Universitas Indonesia.

Suharjito, Didik. 2000. Hutan Rakyat di Jawa. Bogor: Program Penelitian dan Pengembangan Kehutanan Masyarakat (P3KM), Fakultas Kehutanan Institut Pertanian Bogor. 
Suharjito, Didik. 2002. Kebun Talun : Strategi Adaptasi Sosial Kultural dan Ekologi Masyarakat Pertanian Lahan Kering di Desa Buniwangi, Sukabumi, Jawa Barat. Disertasi. Depok: Universitas Indonesia.

Syahadat, Epi. 2001. Kajian Pedoman Penatausahaan Hasil Hutan di Hutan Rakyat Sebagai Dasar Acuan Pemanfaatan Hutan Rakyat. Jurnal Penelitian Sosial dan Ekonomi Kehutanan, Volume 3 Nomor 1, hal. 75-90.

Widayati, Wahyu Tri,. Slamet Riyanto dan Bariatul Himmah. 2005. Kajian Potensi Hutan Rakyat dan Analisis Interaksi Masyarakat dengan Sumberdaya Alam di Kabupaten Boyolali. Jurnal Hutan Rakyat, Volume VII No. 2, hal. 43-79.

Widiyanto. 2010. Strategi Nafkah Rumahtangga Petani Tembakau. Sodality: Jurnal Transdisiplin Sosiologi, Komunikasi, dan Ekologi Manusia Vol. 4, No. 1, hal. 91-114.

Yuniningsih. 2005. Kontribusi Hutan Rakyat Dalam Penyediaan Bahan Baku Industri dan Faktor-Faktor yang Menentukan Keberlanjutannya (Studi Kasus di Kecamatan Nanggung Kabupaten Bogor). Skripsi. Bogor: Institut Pertanian Bogor. 